\title{
The first detailed ornithological description of the island of Žirje (Croatia)
}

\author{
Jenö J. PuRger
}

Jenő J. Purger 2015. The first detailed ornithological description of the island of Žirje (Croatia). - Ornis Hungarica 23(2): 53-61.

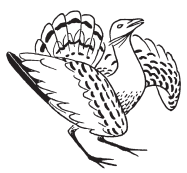

Abstract Ornithofauna of the island of Žirje has not been explored yet. During an early and late survey in September of 2013 and 2014 altogether 50 bird species were recorded, 34 and 41 species was noted including both migratory and resident species in the two parts of the month, respectively. Nine species appeared only at the first half, while 16 species were registered only at the second half of the mouth. The results of this preliminary survey showed the obvious need for more intensive research of the island's bird fauna, with special attention on nesting and wintering birds.

Keywords: Adriatic islands, September, birds, passengers, winter visitors

Összefoglalás Žirje szigetén korábban nem folytak ornitológiai vizsgálatok. 2013 és 2014 szeptemberében 50 madárfaj jelenlétét sikerült kimutatni, közülük 34-et a hónap első, 41-et a hónap második felében. Többségük tipikus vonuló, fészkelő vagy állandó fajnak tekinthetö. Kilenc faj egyedei csak a hónap első, míg 16 faj egyedei csak a hónap második felében fordultak elő. Az előzetes eredmények rámutattak arra, hogy a szigeten költő és telelő fajok felmérése érdekében mielőbb további kutatásokra lenne szükség.

Kulcsszavak: Adriai szigetek, szeptember, madarak, vonulók, telelök

Department of Ecology, Institute of Biology, Faculty of Sciences, University of Pécs, 7624 Pécs, Ifjúság útja 6., Hungary,e-mail:purger@gamma.ttk.pte.hu

BioRes Unlimited Partnership, 7624 Pécs, Barackvirág utca 27., Hungary

\section{Introduction}

The Adriatic islands play an important role in the migration and wintering of birds (Kralj et al. 2013), therefore it is extremely important to study the changes of the bird fauna of each island (Krpan 1970). The Croatian Adriatic coast has long been an interesting study area for ornithologists (Cvitanić 1988, Kralj 1997, Rucner 1998, Lukač 2007), yet many islands, given their large number (Duplančić Leder et al. 2004), have not been sufficiently explored, therefore the ornithofauna of some islands is less known.

The island of Žirje is the $27^{\text {th }}$ largest among the Croatian islands (Duplančić
Leder et al. 2004), but about the bird fauna the only information available was that there are Rock Doves Columba livia (Friganović 1953) and Common Pheasant Phasianus colchicus are bred (Krpan 1976). It is obvious that the ornithofauna of Žirje is not explored, while in the whole area of Šibenik surroundings the presence of 163 bird species is revealed (Krpan 1976).

In the Mediterranean areas, most birds occur during the autumn migration (Krpan 1970), therefore our goal was to explore the bird fauna of island Žirje in this period, and to point out the significance of this island for migratory birds. 


\section{Materials and methods}

\section{Study area}

Island of Žirje lies in the outer group of islands, $22 \mathrm{~km}$ southwest of Šibenik (Figure 1) and extends in the direction of the Dinaric Mts., with a length of $12 \mathrm{~km}$, average width of $1.2 \mathrm{~km}$, and maximum width of $2.5 \mathrm{~km}$ (Smoljanović et al. 1999).

Žirje is the largest $\left(15.8 \mathrm{~km}^{2}\right)$ inhabited island of the Šibenik archipelago, with 103 inhabitants, according to the 2011 census (Buršić 2013). The coast line is 41.76 $\mathrm{km}$ long (Duplančić Leder et al. 2004), and the indentation coefficient is 2.7 (Smoljanović et al. 1999). The geological structure of Žirje island is characterized by the domination of the Upper Cretaceous limestone, which forms two longitudinal ridges extending in the NW-SE direction. In the middle of the island there is a valley covered with a thin layer of overlying red soil with sediments, turned brown (Bognar \& Saletto-Janković 1994).
The highest point on the island is the peak Kapić, $134 \mathrm{~m}$ a.s.l. The settlement, village Žirje lies further from the coast, at the north-eastern part of the field. South of the village is the small lake with fresh water called Lokva. The area of Šibenik archipelago belongs to the Eumediterranean zone characterised by the evergreen forest vegetation of the Quercion ilicis alliance, where the most important associations are Myrto-Quercetum ilicis and Fraxino orni-Quercetum ilicis (Milović \& Pandža 2010). The vegetation on the island consists of macchia, oak forests and the groves of aleppo pine Pinus halepensis, which propagates sub-spontaneously, thus superseding natural vegetation. Most of the area is covered with rocky dry grasslands. The agricultural land consists of vineyards, olive plantations, fig and plum trees, cultivated and abandoned fields (Pandža 2003, Faričić \& Magaš 2004).

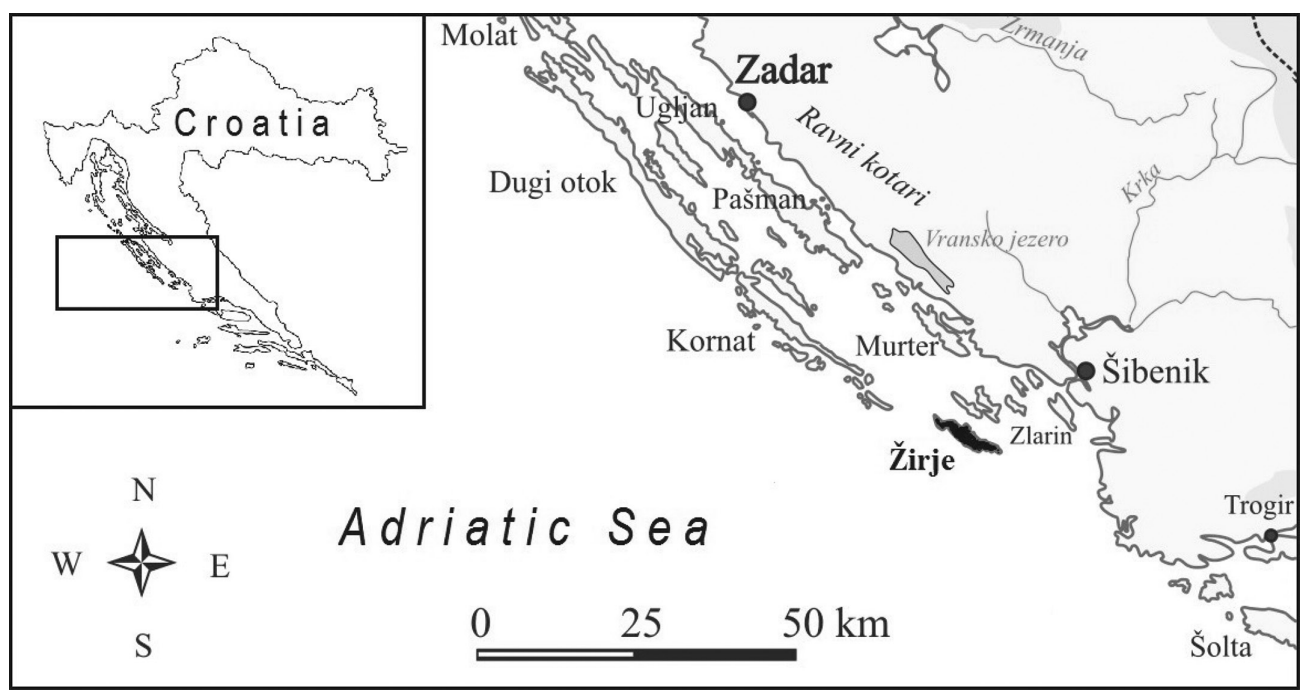

Figure 1 Geographic location of Žirje island in the Adriatic Sea, Croatia 1. ábra Žirje-sziget földrajzi fekvése az Adriai-tengerben Horvátországban 


\section{Data collection}

Observations on the ornithofauna of the island Žirje were carried out between $21^{\text {st }}$ $26^{\text {th }}$ September 2013 and between $5^{\text {th }}-10^{\text {th }}$ September 2014. During migration, birds prefer sites that are similar to the habitats of their own breeding range (Rucner 1998), therefore in both study periods we examined all characteristic habitats on the island e.g. grasslands, forests and macchia, mosaics of cultivated and urbanised areas. Birds were surveyed in the inhabited parts of the island, Žirje, Muna, Mikavica and Koromašna and in bays: Muna, Mikavica, Tratinska, Kruševica, Stupica vela, Stupica mala, Prisiliga, Japlenišće, Šepurina and Koromašna. Research was made with special attention to the central part of the island, where a fresh water pond Lokva and agricultural area Polje can be found. All passable roads of the island were walked through, as well as the hilltops: Vela glava, Muna, Jurkovica, Kapić and Zvizdulje.

The results of observations are summarised in the list of species. The names of orders (in capital letters) and families, and the English and scientific names of birds, as the order of the species in the list have been used according to BirdLife International (2014). If the bird was observed less than five times, the date, location and number of the observed specimens were listed.

\section{Results}

GALLIFORMES, Phasianidae

1. Common Pheasant Phasianus colchicus (Linnaeus, 1758) - Currently it is one of the most commons bird on the island, it can be heard and seen in all habitats, though most- ly in the agricultural areas. During a walk in the field around Lokva sometimes 1520 pheasants were observed. It is an introduced species; it has bred on Žirje from the mid-sixties (Krpan 1976).

\section{COLUMBIFORMES, Columbidae}

2. Rock Dove Columba livia Gmelin, 1789

- Individual birds or small flocks were seen flying over each habitat every day, most often above the bay of Koromašna. On the southern slope of Muna on the stones above the last house in the bay, 10-20 birds gathered regularly. Friganović (1953) mentioned the presence of wild pigeons on Žirje, the observation is certainly related to Rock Dove, which is common resident bird of the island.

\section{CAPRIMULGIFORMES, Apodidae}

3. Common Swift Apus apus (Linnaeus, 1758) - On 26 September 2013 one specimen was observed above Koromašna bay.

PELECANIFORMES, Ardeidae

4. Grey Heron Ardea cinerea Linnaeus, 1758 - On 23 September 2013 one specimen, and on 26 September 2013 nine specimens were observed on the coast near cape Jurkovica in Koromašna bay.

\section{SULIFORMES, Phalacrocoracidae}

\section{European Shag Phalacrocorax aristo-} telis (Linnaeus, 1761) - In both years, in every field trip one to six specimens were observed in every bay around the island. 


\section{CHARADRIIFORMES, Scolopacidae}

6. Common Sandpiper Actitis hypoleucos Linnaeus, 1758 - On 23 September 2013 one specimen was observed in Koromašna bay and one specimen in Stupica vela bay.

CHARADRIIFORMES, Laridae

7. Yellow-legged Gull Larus michahellis J. F. Naumann, 1840 - Birds flying over the island were observed every day. Mostly individual birds or small flocks of 3-6 were observed sometimes flocks of 20-25 birds were seen in larger bays.

\section{ACCIPITRIFORMES, Accipitridae}

8. European Honey Buzzard Pernis apivorus (Linnaeus, 1758) - Four specimens were observed on 26 September 2013 above Polje, south of the settlement Žirje.

9. Short-toed Snake-eagle Circaetus gallicus (Gmelin, 1788) - Above Koromašna bay two specimens were observed on 10 September 2014.

10. Western Marsh Harrier Circus aeruginosus (Linnaeus, 1758) - One male was seen circling above Muna on 25 September 2013 and was flying in south-eastern direction.

11. Eurasian Sparrowhawk Accipiter nisus (Linnaeus, 1758) - In all habitats on the island, usually individual specimens were seen circling in the air, and more often hunting for passerine birds. During the survey this was the most commonly observed predatory bird in both years.

12. Eurasian Buzzard Buteo buteo (Linnaeus, 1758) - Mostly individual birds were observed in both years, but on 9 September 2014 three specimens were seen above Muna and two specimens above Polje near settlement Žirje.

\section{BUCEROTIFORMES, Upupidae}

13. Common Hoopoe Upupa epops Linnaeus, 1758 - On 8 September 2014 one specimen was observed near the road to Šepurina bay, and one specimen in Polje, south of settlement Žirje.

\section{CORACIIFORMES, Meropidae}

14. European Bee-eater Merops apiaster Linnaeus, 1758 - A flock of 22 specimens was observed on 8 September 2014 near the village Žirje, and one day later the distinctive voice of these birds was heard above Koromašna bay.

\section{CORACIIFORMES, Alcedinidae}

15. Common Kingfisher Alcedo atthis (Linnaeus, 1758) - One specimen was observed on 26 September 2013 in Koromašna bay, on 8 September 2014 in Japlenišće, in Koromašna bay and in Lokva, as well as 9 September 2014 in Koromašna bay.

FALCONIFORMES, Falconidae

16. Common Kestrel Falco tinnunculus Linnaeus, 1758 - Usually individual birds were observed in both years, however several times three specimens were seen above Polje and on 25 September 2013 four specimens were observed above Muna. According to my observations at least 6 specimens occur on the island. 
17. Eurasian Hobby Falco subbuteo Linnaeus, 1758 - On 6 September 2014 one specimen was observed in hunting above Jurkovica and Kapić hilltops.

PASSERIFORMES, Corvidae

18. Common Raven Corvus corax Linnaeus, 1758 - In the first half of September 2014 two specimens were observed several times. On 9 September 2014 four specimens were observed above Polje, south of the settlement of Žirje.

19. Hooded Crow Corvus cornix Linnaeus, 1758 - One of the most common birds, during each field trip individual specimens or smaller flocks were observed in every habitat.

\section{PASSERIFORMES, Paridae}

20. Great Tit Parus major Linnaeus, 1758 - One specimen was observed on 23 September 2013 in the surroundings of Stupica vela bay, and two specimens on 25 September 2013 in Polje.

\section{PASSERIFORMES, Hirundinidae}

21. Sand Martin Riparia riparia (Linnaeus, 1758) - Eight Sand Martins came together with Barn Swallow flocks to drink from Lokva on 26 September 2013.

22. Barn Swallow Hirundo rustica Linnaeus, 1758 - On 25 and 26 September 2013 they were seen flying in smaller flocks above Polje, and some of them landed to drink from Lokva. Between 5 and 9 September 2014 often smaller flocks of 3-8 birds were seen above the bay of Muna, Stupica vela, Koromašna, and most often were seen above Polje.
23. Red-rumped Swallow Hirundo daurica Linnaeus, 1771 - Two specimens were observed in flocks of Barn Swallows on 26 September 2013 above Polje in vicinity of Lokva.

24. Northern House Martin Delichon urbicum (Linnaeus, 1758) - 23 specimens were observed on 22 September 2013 above Kapić hilltop, then on 26 September 2013 smaller flocks were flying above Polje, some birds were drinking from Lokva. Three birds were observed on 6 September 2014 near Vela glava hilltop, a day later seven specimens above Zvizdulja hilltop.

\section{PASSERIFORMES, Sylviidae}

25. Eurasian Reed Warbler Acrocephalus scirpaceus (Hermann, 1804) - On 9 September 2014 two specimens were observed on lake of Lokva in Polje south of settlement Žirje.

26. Common Chiffchaff Phylloscopus collybita (Vieillot, 1817) - Individual birds or smaller flocks of 3-6 birds were seen in all habitats, mostly in forests.

27. Wood Warbler Phylloscopus sibilatrix (Bechstein, 1793) - On 6 September 2014 three specimens were observed in the pine forest near Mikavica.

28. Blackcap Sylvia atricapilla (Linnaeus, 1758) - These birds were observed mostly in Polje, where on 25 and 26 September 2013 more then 40-50 were counted, and also 30 birds near Lokva. On 9 September 2014 cc. 30-40 specimens were observed near Lokva.

29. Common Whitethroat Sylvia communis Latham, 1787 - One specimen was ob- 
served on 22 September 2013 near Mikulica in the Aleppo pine forests. On 7 September 2014 there was one specimen in the forest near Draževica, and on 9 September 2014 two specimens on Lokva near Žirje.

30. Orphean Warbler Sylvia hortensis (Gmelin, 1789) - On 25 and 26 September 2013 two specimens were recorded near Lokva, and on 7 September 2014 one in the bushes near Stupica mala bay.

31. Sardinian Warbler Sylvia melanocephala (Gmelin, 1789) - Individual birds were seen regularly in different sites, but mostly in dry habitats.

32. Subalpine Warbler Sylvia cantillans (Pallas, 1764) - Individual birds were seen in all habitats, most of them in macchia.

PASSERIFORMES, Reguliidae

33. Firecrest Regulus ignicapilla (Temminck, 1820) - On 22 September 2013 five specimens were observed near Kapić hilltop, and three specimens near Mikulica in the aleppo pine forests. Three specimens were observed on 23 September 2013 in the southern part of Polje, and also near Stupica vela bay.

PASSERIFORMES, Troglodytidae

34. Winter Wren Troglodytes troglodytes (Linnaeus, 1758) - On 25 September 2013 three specimens were observed near Lokva in the agricultural area of Polje.

PASSERIFORMES, Sturnidae

35. Common Starling Sturnus vulgaris Linnaeus, 1758 - On 26 September 2013 seven specimens were observed near Lokva in Polje.

PASSERIFORMES, Turdidae

36. Eurasian Blackbird Turdus merula Linnaeus, 1758 - Observed in all habitats, mostly individual specimens, except in Polje, where 37 birds were recorded in the early evening on 24 September 2013, while 55 birds were counted on 9 September 2014.

PASSERIFORMES, Muscicapidae

\section{European Robin Erithacus rubecula} (Linnaeus, 1758) - On 23 September 2013 one specimen was observed in the vicinity of Šepurina bay and one specimen near Samograd. On 25 and 26 September 2013 five to seven specimens were observed near Lokva and in Polje. One specimen near Lokve was noted on 9 September 2014.

38. Common Nightingale Luscinia megarhynchos (Brehm, 1831) - Observed only on 9 September 2014 near Lokva, south of the settlement of Žirje.

39. Black Redstart Phoenicurus ochruros (Gmelin, 1774) - One specimen was observed on 23 September 2013 near Šepurina bay and near Samograd. Three specimens were seen on 7 September 2014 near Samograd, one day later there was one bird, and two days later two specimens were seen in Polje.

40. Common Redstart Phoenicurus phoenicurus (Linnaeus, 1758) - One specimen was observed on 23 September 2013 near settlement Žirje. Two and three specimens, respectively, were observed in Polje on 25 and 26 September 2013. In 2014 one 
specimen was noted on lake Lokva near Žirje on 9 September.

41. Whinchat Saxicola rubetra (Linnaeus, 1758) - One specimen was observed on Jurkovica and Kapić hilltops on 22 September 2013.

42. Northern Wheatear Oenanthe oenanthe (Linnaeus, 1758) - On 22 September 2013 three specimens were observed on the Kapić hilltop.

\section{Spotted Flycatcher Muscicapa striata} (Pallas, 1764) - On 7 September 2014 one specimen was observed in the pine forest near Mikavica and near Koromašna bay, a day later in Šepurina bay and in Polje.

\section{European Pied Flycatcher Ficedu-} la hypoleuca (Pallas, 1764) - Usually these birds were observed in the Aleppo pine forests, some specimens were also seen in other habitats in both years, mostly near Mikulica, Jurkovica and Polje. They were seen on 7 September 2014 at Samograd, and a day later in Polje.

\section{PASSERIFORMES, Passeridae}

45. House Sparrow Passer domesticus (Linnaeus, 1758) - Small flocks were observed during both survey periods in Polje near Lokva, and also in settlements. In 2014 around Lokva a flock of 50-60 specimens was observed. On 9 September 2014 twenty birds were counted on an old mulberry tree in the centre of the settlement of Žirje.

46. Spanish Sparrow Passer hispaniolensis (Temminck, 1820) - One specimen was observed on 24 September 2013 near Lokva.
PASSERIFORMES, Motacillidae

47. White Wagtail Motacilla alba Linnaeus, 1758 - Only one specimen was observed on 23 September 2013 in Muna bay.

PASSERIFORMES, Fringillidae

48. Eurasian Chaffinch Fringilla coelebs Linnaeus, 1758 - Flocks of 4-7, 10-15, and 18-20 specimens were observed during the surveys in both years, usually in the vicinity of Lokva and in the whole area of Polje.

49. European Serin Serinus serinus (Linnaeus, 1766) - Two specimens were observed on 25 and 26 September 2013 in abandoned vineyards in Polje, south of the church of St. Maria.

\section{PASSERIFORMES, Emberizidae}

50. Cirl Bunting Emberiza cirlus Linnaeus, 1766 - One specimen was seen on 24 September 2013 near Lokva, and one day later three specimens were observed at the same site. On 26 September 2013 two birds were observed in Polje and also near Lokva. Next year on 9 September one specimen was noted near the settlement of Žirje.

\section{Discussion}

On island of Žirje 50 bird species were recorded in September 2013 and 2014. Altogether 41 bird species were recorded at the end of September 2013, while in the first half of the month in 2014 only 34 species. Some birds were observed only at the beginning of September (C. gallicus, $U$. epops, M. apiaster, F. subbuteo, C. corax, 
A. scirpaceus, Ph. sibilatrix, L. megarchinchos, M. striata), and some species only in the second half of the month (A. apus, A. cinerea, A. hypoleucos, $P$. apivorus, $C$. aeruginosus, $P$. major, $R$. riparia, $H$. dauri$c a, R$. ignicapilla, T. troglodytes, $S$. vulgaris, $S$. rubetra, O. oenanthe, $P$. hispaniolensis, M. alba, S. serinus). These differences point to the dynamics of migration, because species that were recorded only in the first half of the month, except for the Common Raven C. cornix, were migratory birds, while among the birds observed only in the second half of the month there were species that are typically wintering on the Adriatic islands, such as, for example, Firecrest $R$. ignicapilla and Winter Wren T. troglodytes. The Eurasian Sparrowhawk A. nisus is also a typical wintering bird, but on Žirje it can be observed from the beginning of September. Skeleton parts of Common Crane Grus grus (Linnaeus, 1758) were found on September 8, 2014 on the coast of Japljenišće bay, but it is not known exactly when and where the bird had died, therefore it is not on the species list.

The birds mainly stayed near Lokva in Polje, south of the settlement of Žirje. Freshwater attracts both resident and migratory birds, while predatory birds come here to hunting for them. At this habitat the number of recorded birds was the highest, and this was the most suitable place for bird-watching. Lokva has great importance for other animals as well, for example amphibians (Lauš 2010). Visiting bays and hilltops is certainly worthy, because in these habitats other bird species can be seen. There is a great overlapping between ornithofauna of islands with similar habitats and area. On small islands the number of bird spe- cies and their population size are limited, so even small changes, such as environmental degradation or introduced non-native predators can significantly affect their survival (Barun et al. 2010).

In the northern part of the Adriatic Sea, on the western islands of Kvarner bay (Cres, Lošinj and small islands in surroundings) altogether 162 bird species were registered (Sušić 1992). On Šolta island, which is four times larger and much more investigated than Žirje, 132 species are known (Mužinić \& Purger 2012). Bird-watching on Žirje island lasted for a short time and was carried out only in September, therefore the number of registered bird species is in proportion with the number of species known on islands of similar areas, e.g. Iž island, where Lukač et al. (1986) recorded 50 species during a two-week survey in August 1983. Silba is also an island of similar size, where Mužinić and Purger (2013) observed 55 species during a 16-day survey performed on several occasions between 2006-2011. However, together with data from the literature, the ornithofauna of Silba reaches more than 80 species (Mužinić \& Purger 2013). Preliminary results confirmed that there is an obvious need for more intensive research of the bird fauna of Žirje island, with special attention to nesting and wintering birds.

\section{Acknowledgements}

Surveys were performed by support of BioRes Unlimited Partnership. I am grateful for the hospitality of Anka and Valter Dobra from Koromašna. 


\section{References}

BirdLife International 2014. The BirdLife checklist of the birds of the world: Version 7.

Downloaded from: http://www.birdlife.org/datazone/userfiles/file/Species/Taxonomy/BirdLife_ Checklist_Version_70.zip [xls zipped $1 \mathrm{MB}$ ].

Bognar, A. \& Saletto-Janković, M. 1994. Geomorfološke značajke otoka Žirja s arhipelagom [Geomorphological characteristics of the island of Žirje]. - Žirajski libar 1: 169-182. (in Croatian with English Summary)

Buršić, I. (ed.) 2013. Census of population, households and dwellings 2011, population by sex and age. 1468 Statistical Reports. - Croatian Bureau of Statistics, Zagreb, pp. 681

Barun, A., Simberloff, D. \& Budinski, I. 2010. Impact of the small Indian mongoose on native amphibians and reptiles of the Adriatic islands, Croatia. - Animal Conservation 13: 549-555.

Cvitanić, A. 1988. Ornitološka istraživanja na području Dalmacije, Crnogorskog primorja i otoka Jadranskog mora [Ornithological research in Dalmatia, the coast of Montenegro and the islands of the Adriatic Sea]. pp. 127-141. - In: Meštrov, M. \& Sušić, G. (eds.) Orntiologija u Hrvatskoj [Ornithology in Croatia]. - Razred za prirodne znanosti JAZU, Zagreb, pp. 312 (in Croatian with English Summary)

Duplančić Leder, T., Ujević, T. \& Čala, M. 2004. Coastline lengths and areas of islands in the Croatian part of the Adriatic Sea determined from the topographic maps at the scale of 1: 25000 . - Geoadria 9: 5-32.

Faričić, J. \& Magaš, D. 2004. Suvremeni socio-geografski problemi malih hrvatskih otoka - primjer otoka Žirja [Contemporary socio-geographic issues of small Croatian islands - the example of Žirje Island]. - Geoadria 9: 125-158. (in Croatian with English Summary)

Friganović, M. A. 1953. Žirje - prilog poznavanju fiziogeografskih osebina [The island of Žirje - contribution to the knowledge of its physiographic characteristics]. - Geografski glasnik 14-15: 87-98. (in Croatian with French Summary)

Kralj, J. 1997. Ornitofauna Hrvatske tijekom posljednjih dvjesto godina [Croatian ornithofauna in the last 200 years]. - Larus 46: 1-112. (in Croatian with English Summary)

Kralj, J., Barišić, S., Tutiš, V. \& Ćiković, D. (eds.) 2013. Atlas selidbe ptica Hrvatske [Croatian bird migration atlas]. - HAZU Razred za prirodne znanosti, Zavod za ornitologiju, Zagreb, pp. 252 (in Croatian with English Summary)

Krpan, M. 1970. Istureni dalmatinski otoci, otočići i školji kao preletna postaja i gnijezdilište nekih pučinskih vrsta ptica [Protruded islands and isles as temporary stations and nesting places for seabirds]. - Pomorski zbornik 8: 901-906. (in Croatian)

Krpan, M. 1976. Ornitofauna okolice Šibenika [Ornithofauna of the surroundings of Šibenik]. - In: Šibenik - Spomen zbornik o 900. obljetnici. Muzej grada Šibenika, Šibenik. - Posebna izdanja 1: 571586. (in Croatian)

Lauš, B. 2010. A contribution to the herpetofauna of Žirje Island (Dalmatia, Croatia). - Natura Sloveniae 12: 61-63.

Lukač, G. 2007. List of Croatian Birds. Fauna Croatica. Aves XXXVII. - Natura Croatica 16(Suppl.) 1: $1-148$.

Lukač, G., Tomić, D., Makjanić, I. \& Fištrović, J. 1986. Prilog poznavanju ornitofaune srednjedalmatinskih otoka: kratki osvrt na ornitofaunu otoka Iža [Supplement to the understanding of the ornithology of the Middle Dalmatian islands: a short discussion on the ornithology of the island of Iž]. - Larus 36-37: 283-291. (in Croatian with English Summary)

Milović, M. \& Pandža, M. 2010. A contribution to the vascular flora of the Sibenik archipelago islands (Dalmatia, Croatia). - Natura Croatica 19: 179203.

Mužinić, J. \& Purger, J. J. 2012. Ptičji svijet otoka Šolte [Birds of the island Šolta]. - pp. 307-312. - In: Radman, Z. (ed.) Otok Šolta: Monografija [Island Šolta: Monograph]. - Općina Šolta, Grohote, pp. 614 (in Croatian)

Mužinić, J. \& Purger, J. J. 2013. Ptice otoka Silbe i obližnjih Grebena [Birds of island Silba and nearby Grebeni]. pp. 120-131. - In: Mužinić, J. \& Purger, J. J. (eds.) Otok Silba, prirodno i kulturno blago [The island of Silba: a natural and cultural treasure]. - Sveučilište u Zadru, Zadar, pp. 322 (in Croatian with English Summary)

Pandža, M. 2003. Flora of the island of Žirje and the small islands around it. - Acta Botanica Croatica 62: 115-139.

Rucner, D. 1998. Ptice hrvatske obale Jadrana [The birds of Croatian Adriatic coast]. - Hrvatski prirodoslovni muzej, Ministarstvo razvitka i obnove, Zagreb, pp. 311 (in Croatian)

Smoljanović, M., Smoljanović, A. \& Nejašmić, I. 1999. Stanovništvo hrvatskih otoka [Population of Croatian Islands]. - Zavod za javno zdravstvo Županije splitsko-dalmatinske, Split, pp. 482 (in Croatian)

Sušić, G. 1992. Ptice cresko-lošinjske otočne skupine [Birds of Cres-Lošinj island group]. - Otočki ljetopis Cres-Lošinj 8: 145-157. (in Croatian) 